\title{
Comparison of antibody repertories against Staphylococcus aureus in healthy and infected dairy cows with a distinct mastitis history and vaccinated with a polyvalent mastitis vaccine
}

\author{
A. F. Cunha, ${ }^{1,2 *}$ H. M. Andrade, ${ }^{3}$ F. N. Souza,,${ }^{1,2,4,5}$ L. C. Fialho Júnior, ${ }^{3}$ D. L. S. O. Rosa,,${ }^{1,2}$ \\ E. M. Ramos Sanchez, ${ }^{6,7}$ M. Gidlund, ${ }^{8}$ H. Goto, ${ }^{6}$ M. A. V. P. Brito, ${ }^{9}$ A. S. Guimarães, ${ }^{10}$ A. P. Lage, ${ }^{1}$ \\ L. C. Reis, ${ }^{6}$ A. M. M. P. Della Libera, ${ }^{4}$ M. B. Heinemann, ${ }^{11}$ and M. M. O. P. Cerqueira ${ }^{2}$ \\ ${ }^{1}$ Departamento de Medicina Veterinária Preventiva, Escola de Veterinária, Universidade Federal de Minas Gerais, Belo Horizonte 31270-010, \\ Brazil \\ ${ }^{2}$ Departamento de Tecnologia e Inspeção de Produtos de Origem Animal, Escola de Veterinária, Universidade Federal de Minas Gerais, \\ Belo Horizonte 31270-010, Brazil \\ ${ }^{3}$ Departamento de Parasitologia, Instituto de Ciências Biológicas, Universidade Federal de Minas Gerais, Belo Horizonte 31270-901, Brazil \\ ${ }^{4}$ Veterinary Clinical Immunology Research Group, Departamento de Clínica Médica, Faculdade de Medicina Veterinária e Zootecnia, \\ Universidade de São Paulo, São Paulo 05508-270, Brazil \\ ${ }^{5}$ Programa de Pós-graduação em Ciência Animal, Universidade Federal da Paraíba, Areia 58397-000, Brazil \\ ${ }^{6}$ Laboratório de Sorologia e Imunobiologia, Instituto de Medicina Tropical, Universidade de São Paulo, São Paulo 05403-000, Brazil \\ ${ }^{7}$ Departamento de Salud Publica, Facultad de Ciencias de La Salud, Universidad Nacional Toribio Rodriguez de Mendoza de Amazonas, \\ Chachapoyas 01000 , Peru \\ ${ }^{8}$ Departamento de Imunologia, Instituto de Ciências Biomédicas, Universidade de São Paulo, São Paulo 05508-900, Brazil \\ ${ }^{9}$ EMBRAPA-Gado de Leite, Avenida Eugênio do Nascimento, 610, Juiz de Fora 36038-330, Brazil \\ ${ }^{10}$ Departamento de Medicina Veterinária, Universidade Federal de Lavras, Lavras 37200-000, Brazil \\ ${ }^{11}$ Departamento de Medicina Veterinária Preventiva e Saúde Animal, Faculdade de Medicina Veterinária e Zootecnia, Universidade de São Paulo, \\ São Paulo 05508-270, Brazil
}

\section{ABSTRACT}

Staphylococcus aureus is one of the pathogens most frequently isolated from cases of mastitis worldwide. To decrease the effect of $S$. aureus mastitis in dairy farming, alternative strategies for controlling mastitis are needed that depend on a better knowledge of cowto-cow variations in $S$. aureus antibody production. The present study sought to explore the diversity of $S$. aureus antibodies produced by dairy cows with a distinct mastitis history and vaccinated with a polyvalent mastitis vaccine. We obtained protein extracts from $S$. aureus isolates derived from persistent subclinical mastitis. Proteins were fractionated using 2-dimensional gel electrophoresis and Western blotting. Then, Western blotting membranes were exposed to sera from 24 dairy cows that had been divided into the following groups: vaccinated dairy cows that were infected with $S$. aureus, further subdivided according to whether they (a) remained infected by $S$. aureus or (b) recovered from the intramammary infection; unvaccinated dairy cows infected with $S$. aureus; and vaccinated healthy dairy cows with no history of $S$. aureus mastitis. Proteins found to be reactive by Western blot were identified by mass spectrometry (MALDI/TOF-TOF). Our most

Received June 9, 2019.

Accepted November 25, 2019.

*Corresponding author: adrianofcunha@hotmail.com.br important finding was that $\mathrm{F}_{0} \mathrm{~F}_{1}$ ATP synthase subunit $\alpha$, succinyl-diaminopimelate desuccinylase, and cysteinyl-tRNA synthetase were potential candidate proteins for the prevention of $S$. aureus mastitis. This study strengthens the notion that variations among animals should not be ignored and shows that the heterogeneity of antibody production against anti-staphylococcal antigens in animals may enable the identification of new immunotherapy targets.

Key words: Staphylococcus aureus, intramammary infection, serological proteome analysis, immunoproteomics, vaccine

\section{INTRODUCTION}

Bovine mastitis is the disease with the greatest global impact on dairy farming, causing pronounced decreases in milk production and decreased quality of milk and milk derivatives (Ruegg, 2017). Although mastitis has multiple etiologies, only few species, such as Staphylococcus aureus, are prevalent and represent a real problem (Rainard et al., 2018). Moreover, S. aureus is associated with the highest economic losses of all mastitis pathogens (Halasa et al., 2009), in addition to issues related to animal welfare, the environment, public health, and the image of the dairy sector (Hospido and Sonesson, 2005; De Vliegher et al., 2012).

Staphylococcus aureus is a multi-host bacterial pathogen with the capacity to jump into distinct host-species 
populations, making it a major threat to public health and food security (Moura et al., 2018; Richardson et al., 2018). Indeed, S. aureus host-switching events have been linked to the emergence of endemic livestock strains, and cows are the main animal reservoir for the emergence of human epidemic clones (Richardson et al., 2018). To reduce the effect of $S$. aureus mastitis in dairy farming and its implications for public health, alternative strategies for controlling mastitis are needed - such as an effective vaccine - that depend, at least in part, on a better knowledge of cow-to-cow variations in $S$. aureus antibody production.

Staphylococcus aureus is primarily an extracellular pathogen; as a result, host immune responses to this species depend mainly on neutrophil defense mechanisms supported by anti-staphylococcal adaptive humoral responses. Thus, the development of an effective vaccine for combating IMI from $S$. aureus would be most welcome; an effective vaccine that can prevent new IMI has not yet been developed (Misra et al., 2018; Rainard et al., 2018). A great challenge for vaccine research and development is to identify protective antigens (Rainard et al., 2018) that include multiple conserved antigens and afford cross-protection against distinct $S$. aureus strains (Misra et al., 2018).

Our knowledge of the $S$. aureus antigens that are recognized by the host immune system and provide protection against new infections - fundamental for the development of an effective vaccine to control bovine $S$. aureus mastitis - is incomplete (Rainard et al., 2018). This incomplete knowledge may be why vaccines against this agent have not yet yielded great success under field conditions, especially when the aim is to prevent new infections (Pereira et al., 2011; SalgadoPabón and Schlievert, 2014). Dryla et al. (2005) have suggested that antibodies against selected $S$. aureus antigens must be identified in healthy individuals to correlate specific antigens with the immune response of infected individuals.

Based on the information above, we believe that the development of effective new vaccines against $S$. aureus is limited by our lack of knowledge about the proteins encoded by the $S$. aureus genome that are immunogenic and induce protection. Using serum immunoproteomics to develop more effective vaccines is highly desirable, because it is a powerful tool for identifying new antigens. This approach allowed us to obtain a more complete list of $S$. aureus immunogenic proteins, providing a more rational and non-empirical technique for identifying new vaccine candidate antigens (Vytvytska et al., 2002; Dryla et al., 2005; Rueckert and Guzmán, 2012).

Identifying antigenic $S$. aureus proteins that are recognized by antibodies produced in cows (healthy cows, cows with an $S$. aureus IMI, cows that have been cured of an $S$. aureus IMI, or cows that have been infected with but not cured receiving an immune prophylaxis protocol) represents a strategy for discovering novel potential candidate antigens to develop vaccines against bovine mastitis. The present study sought to explore the diversity of antibodies against $S$. aureus produced by dairy cows with a distinct mastitis history and vaccinated with a polyvalent mastitis vaccine.

\section{MATERIALS AND METHODS}

\section{Ethics Statement}

This study was approved by the Animal Research Ethics Committee of the Federal University of Minas Gerais, Brazil, under the protocol number 201/2011.

\section{Herds}

We used approximately 250 lactating Holstein dairy cows belonging to 2 commercial dairy herds (A and B). Of those, $15.75 \%$ from herd A and $24.80 \%$ from herd B were infected with $S$. aureus at the beginning of the study; these animals had high bulk milk SCC $(\geq 500,000$ cells $/ \mathrm{mL})$. All cows were milked twice daily and had estimated average (mean \pm SD) milk yields of $16.68 \pm 0.97 \mathrm{~kg} / \mathrm{d}$ (herd A) and $23.86 \pm 1.30 \mathrm{~kg} / \mathrm{d}$ (herd B). Milking machines were used, and the following mastitis control practices were carried out: forestripping in a strip cup to check for clinical mastitis; predipping ( $0.5 \%$ titratable iodine); drying the teats with a paper towel; and postdipping (3.5\% acid lactic in herd A, and $0.5 \%$ titratable iodine in herd B). Dry cow therapy and treatment of clinical mastitis cases were also adopted. Because both herds had experienced problems with $S$. aureus mastitis, cows with mastitis caused by this pathogen were segregated from the rest of the herd and milked last.

\section{Animals, Samplings, and Vaccination}

We selected 24 lactating dairy cows and took blood samples at 2 time points to divide the animals into 6 groups (Figure 1). First, we identified 14 dairy cows infected with $S$. aureus before vaccination (IPV; d $0)$. Of those, 9 cows were vaccinated, and 5 remained unvaccinated. The group of 9 vaccinated dairy cows was further subdivided at d 118: 7 cows that remained infected by $S$. aureus (IVNC) and 2 cows that had recovered from IMI due to $S$. aureus (IVC). Also at d 118, we identified 3 additional groups: the 5 unvaccinated cows that remained infected (INVI; second 

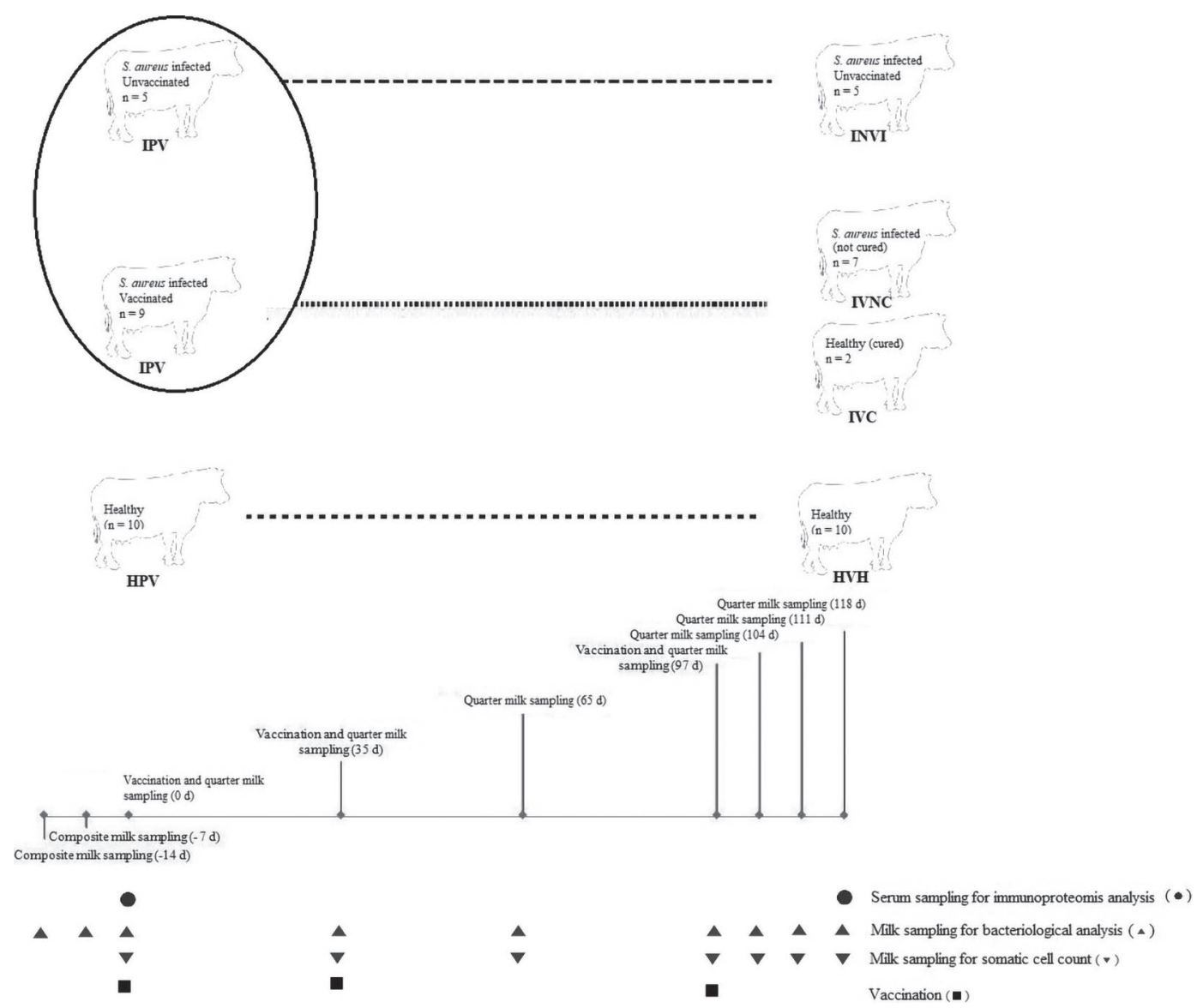

Figure 1. Experimental groups, timeline of vaccination, milking sampling for bacteriological analysis, SCC and serum sampling for immunoproteomics analysis in the study. IPV $=$ infected prior to vaccination; HPV $=$ healthy prior to vaccination; IVC $=$ infected, vaccinated, and cured; IVNC = infected, vaccinated, not cured; INVI = infected, not vaccinated, remained infected; HVH = healthy, vaccinated, and remained healthy. S. Aureus = Staphylococcus aureus.

sampling, d 118) and the 10 vaccinated healthy dairy cows without a history of mastitis caused by major pathogens (HPV; before vaccination, d 0; HVH; after vaccination, d 118). We used a commercially available polyvalent mastitis vaccine (STARTVAC; Hipra, Porto Alegre, Brazil) that contains bacterins for $S$. aureus, CNS, and E. coli.

The cows were selected based on their expected days to dry off, their bacteriological results, and their SCC ( $\leq 200,000$ cells $/ \mathrm{mL}$ for uninfected cows), using the SCC threshold for uninfected quarters according to Schepers et al. (1997) and Schukken et al. (2003). The time scale for the serum sampling for immunoproteomics analysis, vaccination (3 doses), and milk sampling for bacteriological examination and SCC is shown in Figure 1.

\section{Blood Samples}

Blood serum samples were aseptically collected at d 0 (before vaccination) and d 118 after vaccination (21 $\mathrm{d}$ after the third dose of mastitis vaccine) for serological proteome analysis. This strategy allowed us to compare the staphylococcal antibodies before and after vaccination in healthy and infected dairy cows.

\section{Milk Samples}

First, the strip cup test was performed to identify clots, flakes, or otherwise obviously abnormal secretions. Predipping was then performed using a separate towel for each teat. After discarding the first 3 milk streams, the ends of the teats were scrubbed with cotton soaked in $70 \%$ ethanol, and milk samples were aseptically collected into sterile vials for bacteriological analysis (in duplicate). Milk samples were also collected for SCC evaluation. Composite milk samples for bacteriological analysis were collected aseptically twice before vaccination (Figure 1). Quarter milk samples for bacteriological analysis (in duplicate) and SCC were collected aseptically at d 0 (first vaccination), and at $\mathrm{d}$ 
35 (second vaccination), 65, 97 (third vaccination), 104, 111, and $118 \mathrm{~d}$ after the first vaccination (Figure 1). The milk samples were kept at $4^{\circ} \mathrm{C}$ until their arrival at the laboratory. The milk samples used for bacteriological analysis were stored at $-20^{\circ} \mathrm{C}$ until analysis.

\section{IMI Definition}

A sample was defined as having an $S$. aureus IMI if at least 1 colony $(\geq 100 \mathrm{cfu} / \mathrm{mL})$ was visible after growth in bacteriological culture. The milk sample was also regarded as bacteriologically positive, and the quarter was regarded as not bacteriologically cured of $S$. aureus if this pathogen was isolated from at least 1 of the duplicate samples. A quarter was regarded as uninfected at the beginning of the experiment based on 2 composite bacteriologically negative results before vaccination (d -7 and -14 ), and a milk quarter bacteriologically negative result (in duplicate) on the day of vaccination, as well as $\mathrm{SCC} \leq 200,000$ cells $/ \mathrm{mL}$ in all quarters. An infection was considered cured if 2 consecutive monthly milk samples or 3 consecutive weekly milk samples did not show the causative organism, as described by Schukken et al. (2014).

\section{Somatic Cell Count}

Composite and quarter milk samples for SCC were collected in $40-\mathrm{mL}$ vials containing microtablets of bronopol (2-bromo-2-nitropane-1,3-diol). The SCC measurements were performed using an automated fluorescence microscopic somatic cell counter (Somacount 300; Bentley Instruments, Chaska, MN).

\section{Bacteriological Analysis}

Bacteriological analysis was conducted by culturing $0.01 \mathrm{~mL}$ of each sample on $5 \%$ ovine blood agar plates. The plates were incubated for 24 to $48 \mathrm{~h}$ at $37^{\circ} \mathrm{C}$ followed by Gram stain, observation of colony morphology and hemolysis patterns, and biochemical testing (Oliver et al., 2004; Souza et al., 2016).

\section{Bacterial Strains and Growth Conditions}

We obtained $S$. aureus proteins from $6 S$. aureus samples isolated from the milk of cows with persistent subclinical mastitis. We confirmed the identification of previously selected $S$. aureus isolates via biochemical tests using PCR to determine the presence of fem $A$ and thermonuclease $(n u c)$ genes (present in all $S$. aureus isolates), as described by Mehrotra et al. (2000) and Sasaki et al. (2010). We characterized the S. aureus isolates using highly discriminating genetic marker pulsed-field gel electrophoresis (PFGE) according to McDougal et al. (2003) to determine whether the selected isolates belonged to different pulsetypes or subtypes. We interpreted the DNA fragment patterns of the PFGE as described by van Belkum et al. (2007).

The S. aureus isolates were grown in RPMI-1640 medium (cat. no. R6504, Sigma-Aldrich, Saint Louis, MO) supplemented with deferoxamine $(0.15 \mathrm{~m} M$; cat. no. D9533, Sigma-Aldrich) under anaerobic conditions until the early stationary growth phase, as described by Le Maréchal et al. (2009). The in vitro growth conditions we used were those that most closely mimicked in vivo growth conditions during mastitis, as proposed by Le Maréchal et al. (2009).

\section{S. aureus Protein Extraction}

We performed $S$. aureus protein extraction according to the method described by Le Maréchal et al. (2009). Briefly, after bacteria growth in iron-depleted medium under anaerobic conditions, the samples were centrifuged at $5,000 \times g$ for $5 \mathrm{~min}$ at $4^{\circ} \mathrm{C}$ to obtain the cell pellet, and washed twice in ice-cold PBS $(2.1 \mathrm{mM}$ $\left.\mathrm{NaH}_{2} \mathrm{PO}_{4}, 8.3 \mathrm{M} \mathrm{Na}_{2} \mathrm{HPO}_{4}, 6.7 \mathrm{M} \mathrm{NaCl}, \mathrm{pH} 7.2\right)$ and further washed in digestion buffer $(10 \mathrm{~m} M$ Tris- $\mathrm{HCl}, 1$ $\mathrm{m} M$ EDTA, $5 \mathrm{mM} \mathrm{MgCl}_{2}$, pH 7.6). To obtain the cell surface proteins, the cell pellet was resuspended in $1 \mathrm{~mL}$ of the digestion buffer containing 35\% raffinose (cat. no. R0250; Sigma-Aldrich), $10 \mu \mathrm{L}$ of protease inhibitor cocktail (GE Healthcare, Orsay, France), $1 \mathrm{~m} M$ phenymethanesulfonyl fluoride (PMSF; Sigma-Aldrich), and $50 \mu \mathrm{L}$ of lysostaphin (cat. no. L7386; Sigma-Aldrich). After incubation at $37^{\circ} \mathrm{C}$ for $30 \mathrm{~min}$, surface proteins and protoplasts were separated by centrifugation at $2,500 \times g$ for $10 \mathrm{~min}$. The supernatant containing the protoplasts and debris was discarded. Protein concentration was determined using the Bradford method (Bradford, 1976), and the supernatant were stored at $-80^{\circ} \mathrm{C}$ for further analysis.

\section{Protein Separation by 2-Dimensional Gel Electrophoresis}

Protein separation by 2-dimensional gel electrophoresis was performed according to the method of Vieira et al. (2014) with some modifications. The $S$. aureus protein pool was subjected to separation by 2-dimensional gel electrophoresis, isoelectric point, and molecular weight. We used Immobiline DryStrips (GE Healthcare, Piscataway, NJ) with a size of $18 \mathrm{~cm}$ and a $\mathrm{pH}$ of 4 to 7 . The strips were hydrated for $12 \mathrm{~h}$ at room temperature in a solution containing $350 \mu \mathrm{L}$ of protein 
extract, $3.5 \mu \mathrm{L}$ of immobilized $\mathrm{pH}$ gradient buffer, $\mathrm{pH}$ 4 to 7 , and isoelectric focusing buffer. The strips were then subjected to isoelectric focusing at $50 \mu \mathrm{A} /$ gel to separate the molecules according to their isoelectric points in an Ettan IPGPhor 3 (GE Healthcare). The electrophoresis conditions for isoelectric focusing were as follows: $0.5 \mathrm{kV}$ for $10 \mathrm{~h}, 1 \mathrm{kV}$ for $90 \mathrm{~min}$, and $8 \mathrm{kV}$ for $60 \mathrm{~min}$, followed by a gradual increase to $40 \mathrm{kV}$ in $0.5 \mathrm{kV}$ increments over $1 \mathrm{~h}$, all at $20^{\circ} \mathrm{C}$.

For protein reduction and alkylation, the strips were placed in conical tubes containing $2.5 \mathrm{~mL}$ of equilibration buffer $(50 \mathrm{~m} M$ of $1.5 M$ Tris, $\mathrm{pH} \mathrm{8.8,6} M$ urea, $30 \%$ glycerol, $2 \%$ SDS, $0.001 \%$ vol $/$ vol $0.5 \%$ bromophenol blue, and $10 \mathrm{mg} / \mathrm{mL}$ dithiothreitol) for $15 \mathrm{~min}$ with gentle stirring. The solution was then replaced with $2.5 \mathrm{~mL}$ of equilibration buffer containing $25 \mathrm{mg} /$ $\mathrm{mL}$ iodoacetamide instead of dithiothreitol. The strips were quickly washed in 10\% Tris-glycine buffer, placed horizontally on $12 \%$ polyacrylamide gels, and overlaid with $0.5 \%$ agarose that had been melted at $45^{\circ} \mathrm{C}$ and that contained $0.002 \%$ bromophenol blue. Then, $5 \mu \mathrm{L}$ of a prestained molecular weight marker mixture with a mass range of 6 to $180 \mathrm{kDa}$ (BenchMark Pre-Stained Protein Standard; cat. no. 10748-010; Novex, Carlsbad, CA) was also added to a well. Electrophoresis was performed at $50 \mathrm{~V} /$ gel and $25 \mathrm{~mA} /$ gel for the initial $15 \mathrm{~min}$, and then at $100 \mathrm{~V} /$ gel and $50 \mathrm{~mA} /$ gel at $10^{\circ} \mathrm{C}$ until separation of the protein molecular weight markers was complete. The gels used to assay protein transfer to membranes and for Western blotting were not stained; some 2-dimensional gel electrophoresis gels were stained using Coomassie Blue according to Neuhoff et al. (1988) and scanned using an ImageScanner (Amersham Biosciences, Little Chalfont, UK) and ImageScanner software (GE Healthcare).

\section{Western Blotting}

Following electrophoresis, proteins were transferred from the unstained gels to Hybond $\mathrm{C}$ nitrocellulose membranes (cat. no. 10600023, GE Healthcare) by wet electroblotting using the Mini Trans-Blot Cell (cat. no. 170-3930, Bio-Rad, Hercules, CA) or by Sistema semidry electroblotting using a Semidry-transfer Unit (cat. no. 11001342, GE Healthcare) according to the manufacturer's instructions (da Fonseca Pires et al., 2014). The nitrocellulose membranes were then blocked with Block Buffer (PBS containing 0.3\% Tween 20 and $3 \%$ skim milk powder) and incubated overnight with pooled serum samples from cows from the experimental groups at 1:150 dilution in $25 \mathrm{~mL}$ of Tris-buffered saline containing $0.3 \%$ Tween 20 and $3 \%$ skim milk powder.
Following incubation with the diluted serum from each of the 6 groups, the mouse anti-bovine IgG antibody conjugated to horseradish peroxidase (cat. no. A5295, Sigma-Aldrich) was added at a dilution of 1:1,000. The membrane was incubated for $1 \mathrm{~h}$ at room temperature under agitation and then developed with ECL Prime (cat. no. RPN2231, GE Healthcare) using StarLight RGBII (Vilber Loumart, Paris, France).

Following protein separation by 2-dimensional gel electrophoresis and Western blotting, we performed an analysis to determine the number of spots that were common to the gel and membrane replicates. All gels, including the Western blotting, were repeated 3 times. The spots that were excised for mass spectrometry were performed in 1 gel from each group, selected based on previous spots detected using Western blotting. The gels and membranes with the most common spots among replicates were selected for analysis, spot excision, and identification of the eluted proteins by mass spectrometry.

\section{Protein Identification by MS}

Enzymatic Digestion of Gel-Separated Proteins. The selected spots were excised from the gels, placed in glass Petri dishes, washed with methanol, and cut into segments of approximately $2 \mathrm{~mm}^{3}$. The gel fragments were placed in microtubes with destaining solution [50\% acetonitrile (ACN) in $25 \mathrm{mM}$ ammonium bicarbonate, $\mathrm{pH} 8.0]$ and stirred in a vortex mixer for 15 min between washes until the stain was completely removed. The destaining solution was removed, and the gel was dehydrated in $100 \% \mathrm{ACN}$ for $5 \mathrm{~min}$. The ACN was discarded, and the process was repeated until complete dehydration of the gel was achieved, verified by its white opacity.

For enzymatic digestion of proteins, $10 \mu \mathrm{L}$ of $20 \mathrm{ng} /$ $\mu \mathrm{L}$ trypsin solution and $20 \mu \mathrm{L}$ of $50 \mathrm{mM}$ ammonium bicarbonate solution were added to the microtubes while the sample was on ice. The samples were then placed in a water bath at $37^{\circ} \mathrm{C}$ for 16 to $24 \mathrm{~h}$ to achieve complete protein digestion and fragmentation.

The resulting extract containing trypsin ammonium bicarbonate and a portion of the peptides was transferred to a new $500-\mu \mathrm{L}$ microtube. Then, $30 \mu \mathrm{L}$ of a solution containing $5 \%$ formic acid and $50 \%$ ACN was added to the tube containing the remaining gel fragments and stirred for $30 \mathrm{~min}$. The resulting peptide extract was added to the $500-\mu \mathrm{L}$ microtube containing the initial extract. The extraction with formic acid and ACN was repeated, and all partial extracts were combined in the $500-\mu \mathrm{L}$ microtube. The peptide extracts 
were concentrated using Concentrator Plus (Eppendorf, Hamburg, Germany) to a final volume of $10 \mu \mathrm{L}$.

Peptide Purification with ZipTips. Protein purification was performed using Reverse-Phase ZipTip C18 pipette tips (Millipore, Burlington, MA) for peptide desalinization and concentration. The ZipTips were equilibrated by aspirating and dispensing $8 \mu \mathrm{L}$ of $50 \%$ ACN and $0.1 \%$ trifluoroacetic acid (TFA) 3 times. This procedure was followed by aspirating and dispensing $8 \mu \mathrm{L}$ of $0.1 \%$ TFA 3 times. Protein binding to the ZipTip columns was achieved by aspirating and dispensing the peptide samples 7 to 10 times for maximum binding, because the protein extracts are complex mixtures. The columns were then washed by aspirating and discarding $10 \mu \mathrm{L}$ of $0.1 \%$ TFA 3 times. The peptides were eluted from the column tips by aspirating and dispensing $6 \mu \mathrm{L}$ of $50 \% \mathrm{ACN}$ in $0.1 \%$ TFA into a new microtube 10 times.

Mass Spectrometry. The peptide samples were diluted in $50 \%$ ACN in $0.1 \%$ TFA, mixed with $\alpha$-cyano-4hydroxycinnamic acid matrix (Aldrich, Milwaukee, WI) and applied to an MTP AnchorChip 600/384 (Bruker Daltonics, Billerica, MA).

Mass spectrometry analyses were performed using an Autoflex III MALDI-TOF/TOF mass spectrometer (Bruker Daltonics) operated in positive mode and controlled by FlexControl software. Calibration was performed using Peptide Calibration Standard II (Bruker Daltonics). Contaminant protein peaks such as trypsin and keratin were excluded from the data bank search. Spectra were produced by accumulating data from 200 consecutive laser shots using a neodymium-doped yttrium aluminum garnet laser.

The resulting fragmentation spectra from tandem mass spectrometry were analyzed to determine the peptide molecular mass using MASCOT software (Matrix Science, London, UK). The peptides were identified by comparing the calculated $\mathrm{m} / z$ (mass to generated ion charge ratio) of the experimental fragments with those of predicted fragments obtained from the MSDB data bank.

\section{Data Analysis}

Protein size, molecular mass, and isoelectric points were obtained from the UniProt databases (www .uniprot.org). Protein localization in the cell was predicted by PSORT (http://psort.hgc.jp/), and transmembrane domains were predicted by the TMpred database (www.ch.embnet.org/software/TMPRED_form .html). Categorical functions were analyzed using the BRITE hierarchy command of the Kyoto Encyclopedia of Genes and Genomes database (www.genome.jp/ kegg/brite.html).

\section{RESULTS}

The 6 staphylococcal isolates used in the present study pertained to distinct pulsotypes or subpulsotypes determined by PFGE analysis, because they differed by at least one band (data not shown). Reactive spots detected by Western blotting exhibited molecular masses between approximately 26 and $80 \mathrm{kDa}$ (Table 1). A total of 59 spots were selected and excised from the 2-dimensional gel electrophoresis gel for identification by MS (Figure 2). Of the 59 selected spots, 53 (89.8\%) were identified and corresponded to 42 non-redundant proteins (Table 1).

Of the 42 non-redundant proteins, $25(59.5 \%)$ were predicted to be localized in the bacterial cell cytoplasm, and $17(40.5 \%)$ were surface-bound proteins. Of the 17 surface-bound proteins, $6(35.3 \%)$ were located on the membrane, and $11(64.7 \%)$ were transmembrane (i.e., exhibiting regions that crossed the cell membrane or possessing structural sites that were exposed to the immune system). The majority of the antigenic proteins $(68.3 \%)$ were enzymes involved in metabolic processes of the bacterial cell, especially enzymes involved in protein synthesis or carbohydrate metabolism for energy production (Table 1).

The nitrocellulose membrane incubated with the sera of animals from the IPV group exhibited a greater number of spots than the membrane incubated with the sera of animals from the HPV group (Figure 3). In contrast, the membrane incubated with the sera of healthy animals from the IVC group exhibited a lower number of spots than the membranes incubated with the sera of animals from the remaining groups (Figures 4 and 5).

Among the 42 identified proteins, animals from the IPV and HPV groups exhibited a humoral immune response to 27 proteins (64.3\%; Figure 3). Specifically, 14 $(51.8 \%)$ of the proteins were common to both groups; of these, $8(57.1 \%)$ were cytosolic and $6(42.9 \%)$ were surface-bound.

We found that $\mathrm{F}_{0} \mathrm{~F}_{1}$ ATP synthase subunit $\alpha$ (SAS) and succinyl-diaminopimelate desuccinylase (SDD) were reactive with the sera of uninfected animals but not with the sera of infected animals (Figure 3).

At the end of the experiment, we had found 15 $(35.7 \%)$ previously unidentified proteins (Figures 4 and 5); of these, $4(26.7 \%)$ were surface-bound, and 11 $(73.3 \%)$ were cytosolic. Of the 15 proteins, $12(80 \%)$ were reactive with the sera of both infected and uninfected animals in the vaccinated groups. The remaining 3 proteins (20\%) were reactive only with the sera of infected animals that had not been vaccinated (INVI).

We found that 13 proteins were reactive with the sera of IPV and INVI animals (i.e., non-vaccinated infected 


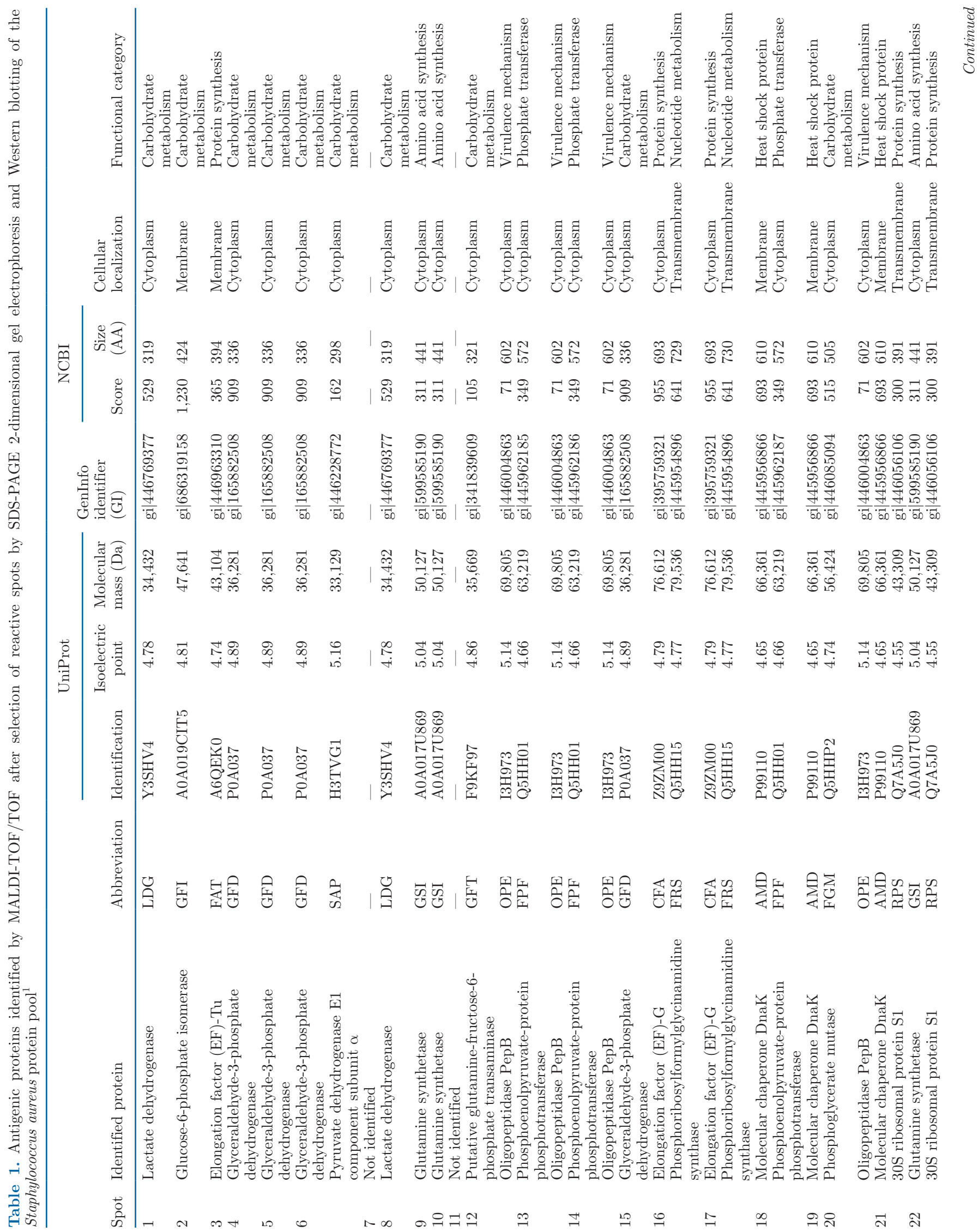




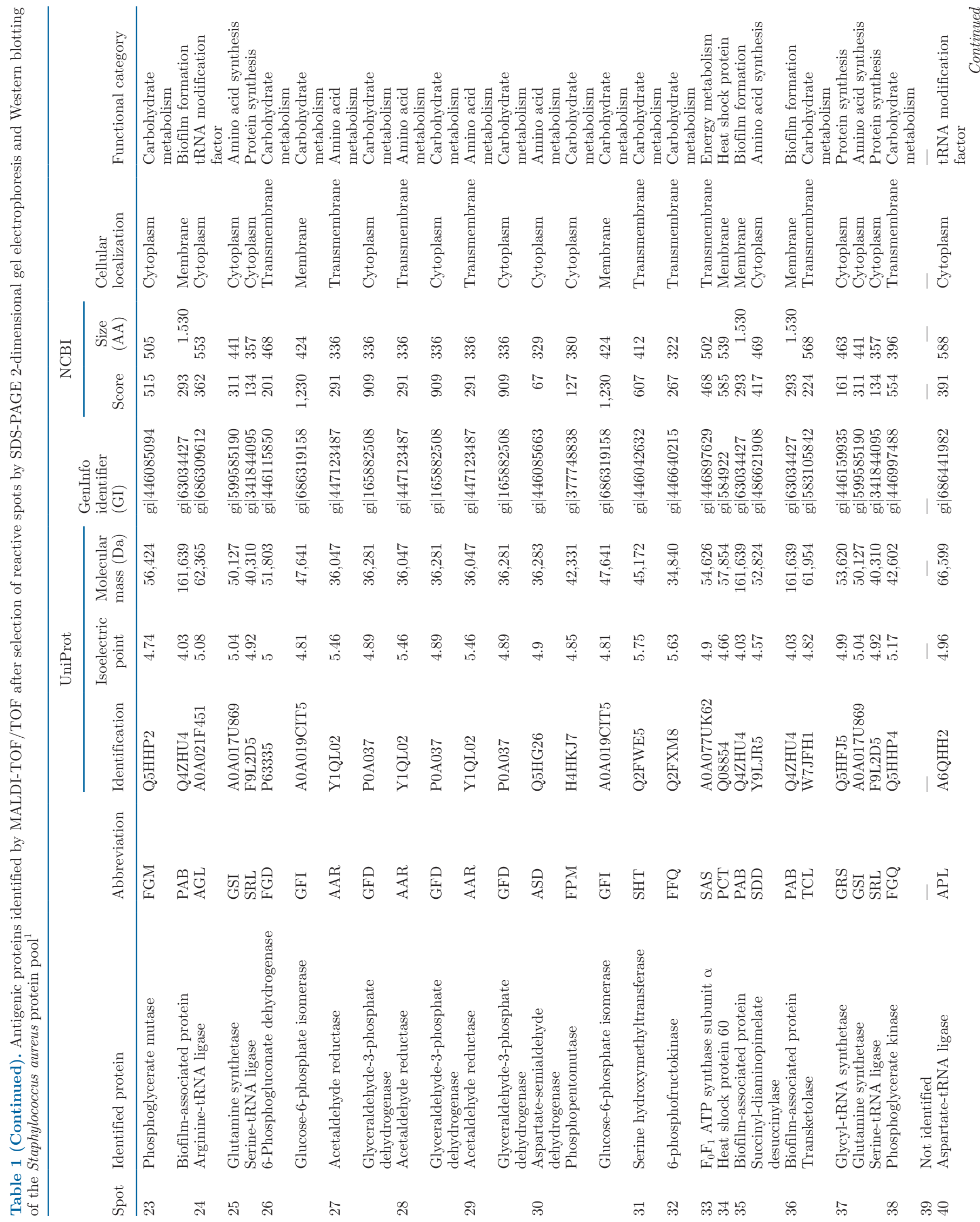


Cunha et al.: STAPHYLOCOCCUS AUREUS MASTITIS VACCINE

4596

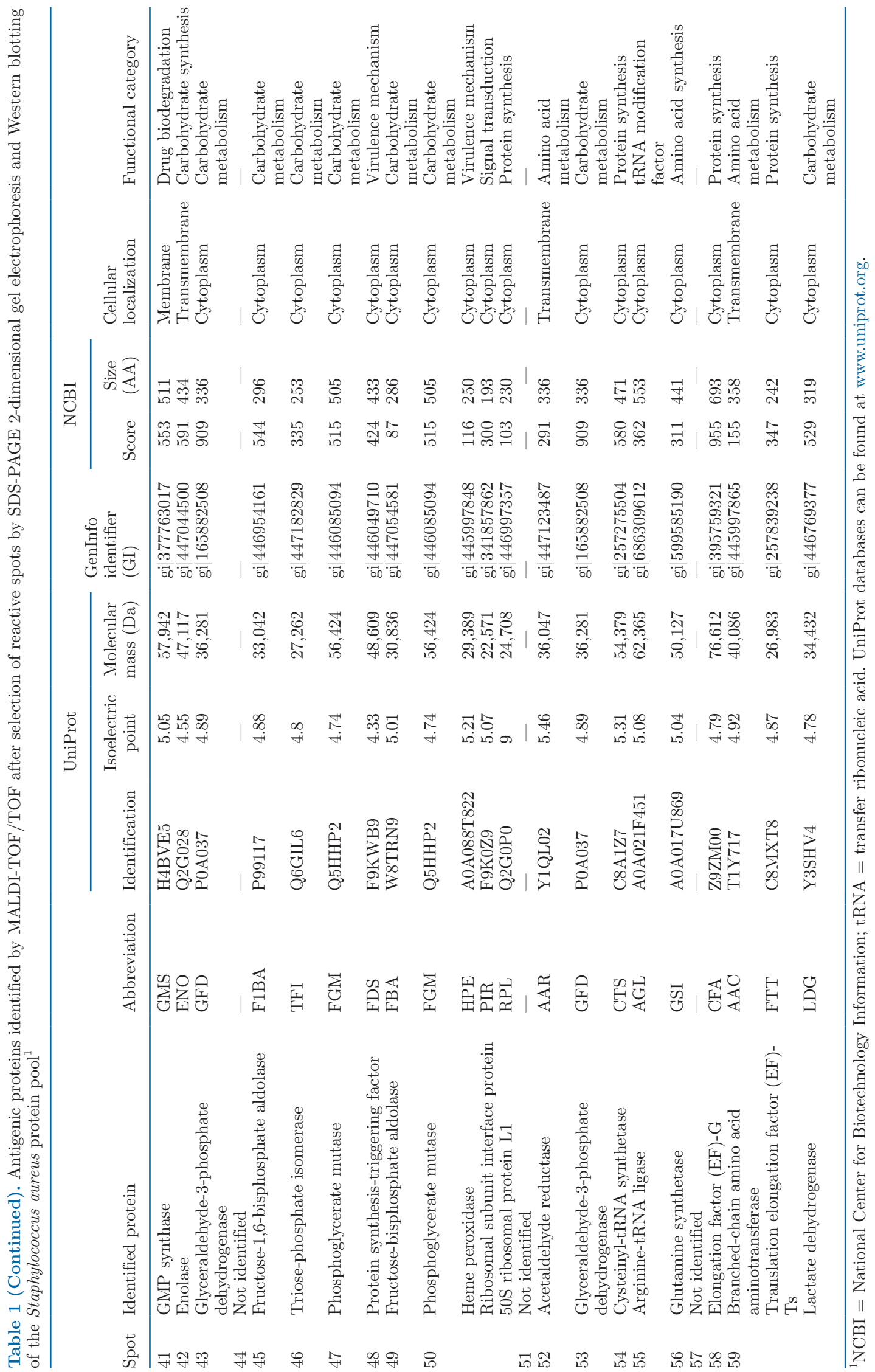



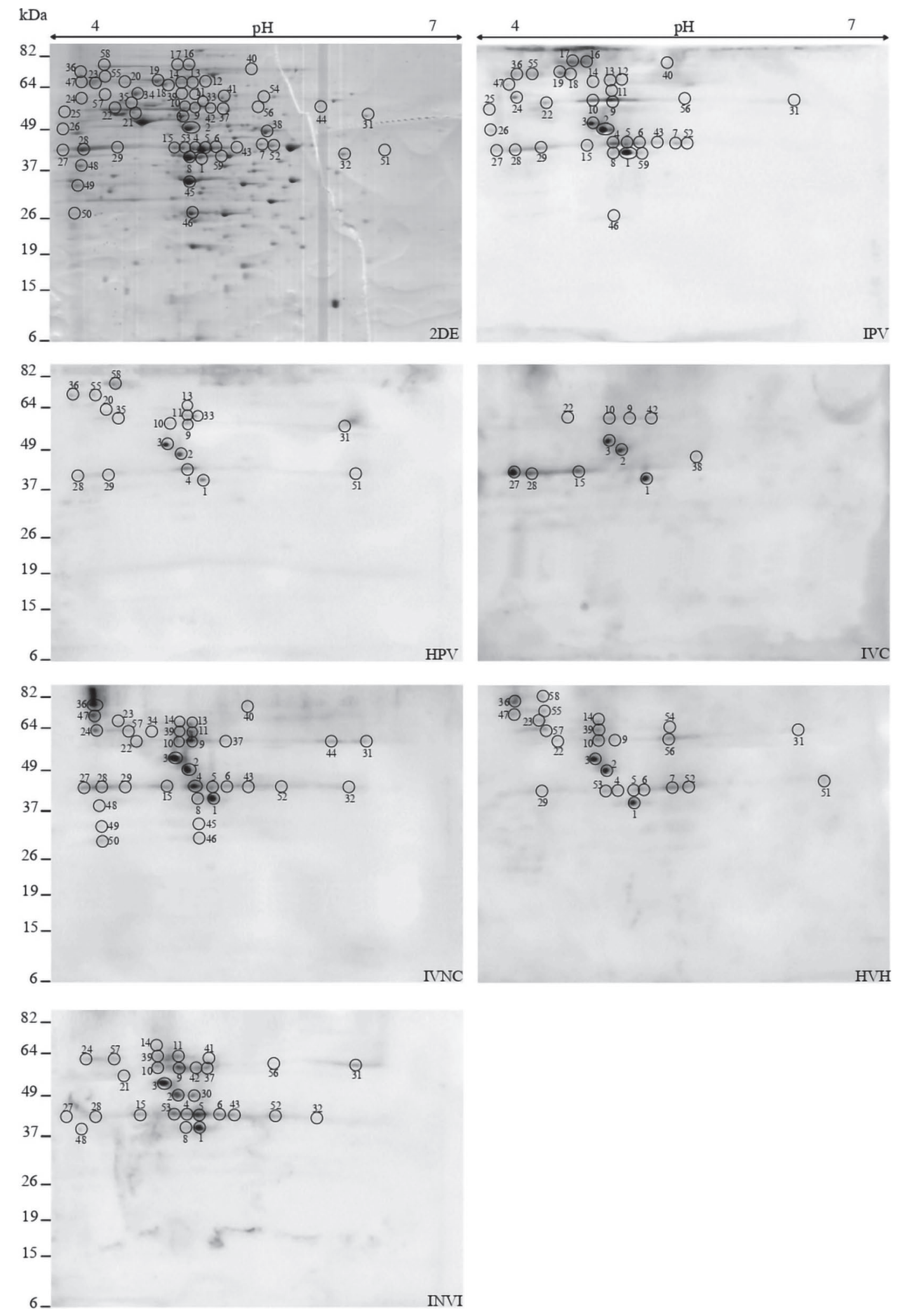

Figure 2. After 2-dimensional gel electrophoresis (2DE) and Western blotting, reactive spots were selected for identification of Staphylococcus aureus proteins. Sera were from the following animal groups: IPV $=$ infected prior to vaccination; HPV $=$ healthy prior to vaccination; IVC $=$ infected, vaccinated, cured; IVNC = infected, vaccinated, not cured; HVH = healthy, vaccinated, remained healthy; INVI = infected, not vaccinated, remained infected. 
animals; Figure 4). Branched-chain amino acid aminotransferase (AAC), 6-phosphogluconate dehydrogenase (FGD), phosphoribosylformylglycinamidine synthase (FRS), translation elongation factor Ts (FTT), and putative glutamine-fructose-6-phosphate transaminase (GFT) were recognized by IPV animals. Aspartatesemialdehyde dehydrogenase (ASD), phosphopentomutase (FPM), 6-phosphofructokinase (FFQ), protein synthesis-triggering factor (FDS), glycyl-tRNA ligase (GRS), GMP synthase (GMS) and enolase (ENO) were recognized by INVI animals (Figure 4).

Only 9 proteins were reactive with the sera of cured animals (Figures 4 and 5). Vaccination was exclusively responsible for stimulating the production of antibodies against the transmembrane protein phosphoglycerate kinase (FGQ) in cured animals. Although ENO was reactive with the sera of INVI animals, vaccination of infected animals was responsible for stimulating the production of specific anti-ENO antibodies, resulting in the recovery of infected animals.

In uninfected vaccinated animals $(\mathrm{HVH})$, vaccination was responsible for stimulating the production of specific antibodies against cysteinyl-tRNA synthetase (CTS), 30S ribosomal protein S1 (RPS), and pyruvate dehydrogenase E1 component subunit $\alpha$ (SAP), given that the remaining proteins were previously reactive to the sera of HPV animals (Figure 5). The INVI and IVNC animals exhibited antibody production against RPS and SAP, but the sera of infected animals were not reactive with CTS (Figures 4 and 5).

Vaccination was also responsible for inducing the production of specific anti-staphylococcal antibodies against fructose-1,6-bisphosphate aldolase (F1BA), fructose-bisphosphate aldolase (FBA), 50S ribosomal protein L1 (RPL), heme peroxidase (HPE), heat shock protein 60 (PCT), and ribosomal subunit interface protein (PIR) in dairy cows that had not been cured of $S$. aureus IMI (IVNC), given that these proteins were not reactive with the sera of IPV animals (Figure 4).

\section{DISCUSSION}

Immunoproteomics approaches have been used to identify relevant immunoreactive candidate antigens from bovine-associated $S$. aureus (Tedeschi et al., 2009; Misra et al., 2018). Nevertheless, none of the previous studies have addressed the heterogeneity of anti-staphylococcal antibody production by dairy cows with a

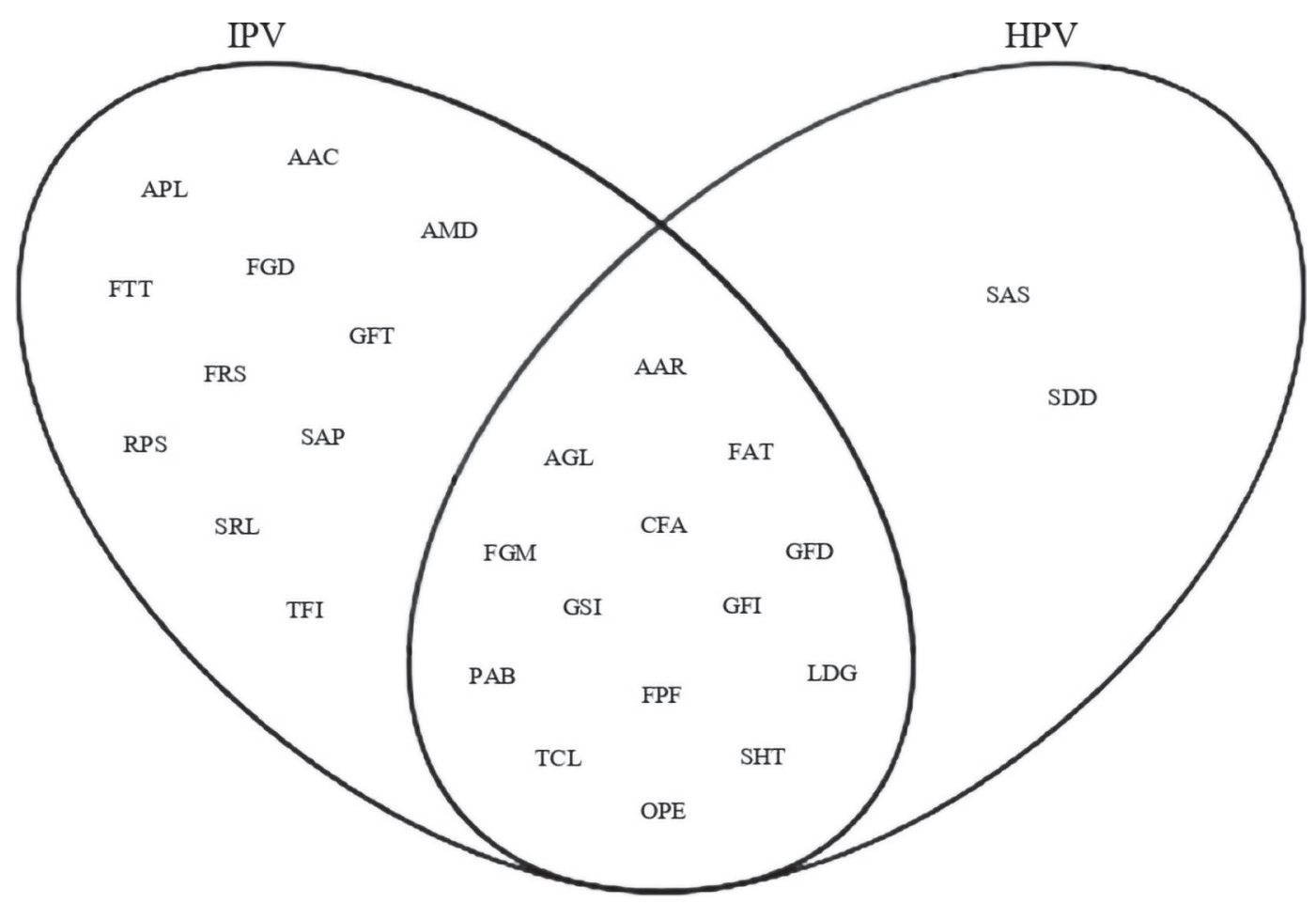

Figure 3. Staphylococcus aureus proteins reactive with sera from animals from the infected prior to vaccination (IPV) and healthy prior to vaccination (HPV) groups. Venn diagram of $S$. aureus reactive proteins that were selected after 2-dimensional gel electrophoresis and Western blotting using sera from dairy cows from the IPV and HPV groups, and identified by MALDI-TOF/TOF. The abbreviations correspond to identified proteins listed in Table 1. 
distinct $S$. aureus mastitis history. We speculated that susceptibility or resistance to disease and the elimination of IMI caused by $S$. aureus (spontaneous cure) would correlate with the production of different antistaphylococcal antibodies or the production of different levels of anti-staphylococcal antibodies by individuals. Considering the high prevalence of $S$. aureus and bulk milk SCC in the dairy herds investigated in this study, the comparison of antibodies produced by healthy dairy cows that were exposed to $S$. aureus but remained healthy with antibodies produced by animals that did not remain healthy allowed us to identify antibodies against specific $S$. aureus proteins that may contribute to disease resistance. Furthermore, the comparison of $S$. aureus proteins recognized by antibodies from chronically infected dairy cows that were cured of $S$. aureus IMI after vaccination with proteins recognized by antibodies from animals that were vaccinated but remained chronically infected allowed us to identify potential antigens associated with the elimination of IMI caused by $S$. aureus. Most studies have focused on the virulence factors of the pathogen as a basis for developing vaccines against IMI in dairy cows, but this approach has failed. We believe that the problem must

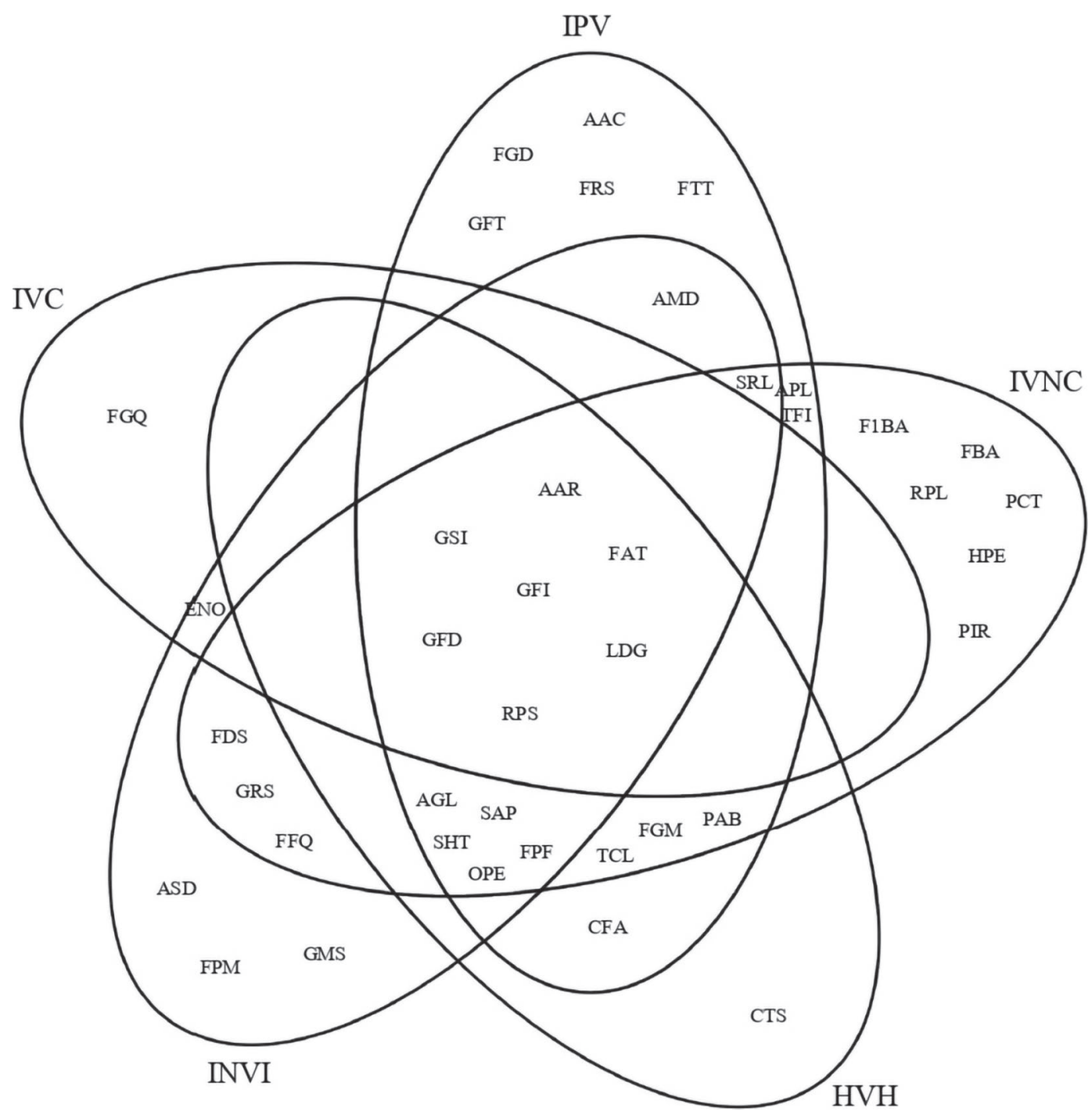

Figure 4. Staphylococcus aureus proteins reactive with sera from animals from the infected prior to vaccination (IPV); infected, vaccinated, and cured (IVC); infected, vaccinated, not cured (IVNC); infected, not vaccinated, remained infected (INVI); and healthy, vaccinated, and remained healthy $(\mathrm{HVH})$ groups. Venn diagram of $S$. aureus reactive proteins that were selected after 2-dimensional gel electrophoresis and Western blotting using sera from dairy cows from the IPV, IVC, IVNC, INVI, and HVH groups, and identified by MALDI-TOF/TOF. The abbreviations correspond to identified proteins listed in Table 1. 
be viewed from other perspectives, such as mapping the responses of animals that have mounted successful pathogen-host immune responses; in this way, we may uncover potential novel targets that provide a basis for the development of alternative therapeutics (Rainard et al., 2018).

In this study, we first attempted to target antibodies against cell surface staphylococcal antigens, because they are essential in the early stages of $S$. aureus infection and dissemination (Anderson et al., 2012). Although we used a method to extract mainly cell surface staphylococcal antigens proteins that involved the use of lysostaphin and raffinose (Le Maréchal et al., 2009), it did not exclusively isolate surface proteins. By digesting cell wall peptidoglycans, lysostaphin reduces the rigidity of the cell wall, rendering protoplasts osmotically fragile and causing cytosolic extravasation (Francius et al., 2008).

Holtfreter et al. (2010) showed that antibody responses to cytosolic proteins are less common than those to surface proteins. However, the authors presumed that the localization of cytosolic proteins was not restricted to the cytoplasm. Many S. aureus cell wall proteins are also cytoplasmic, particularly proteins related to

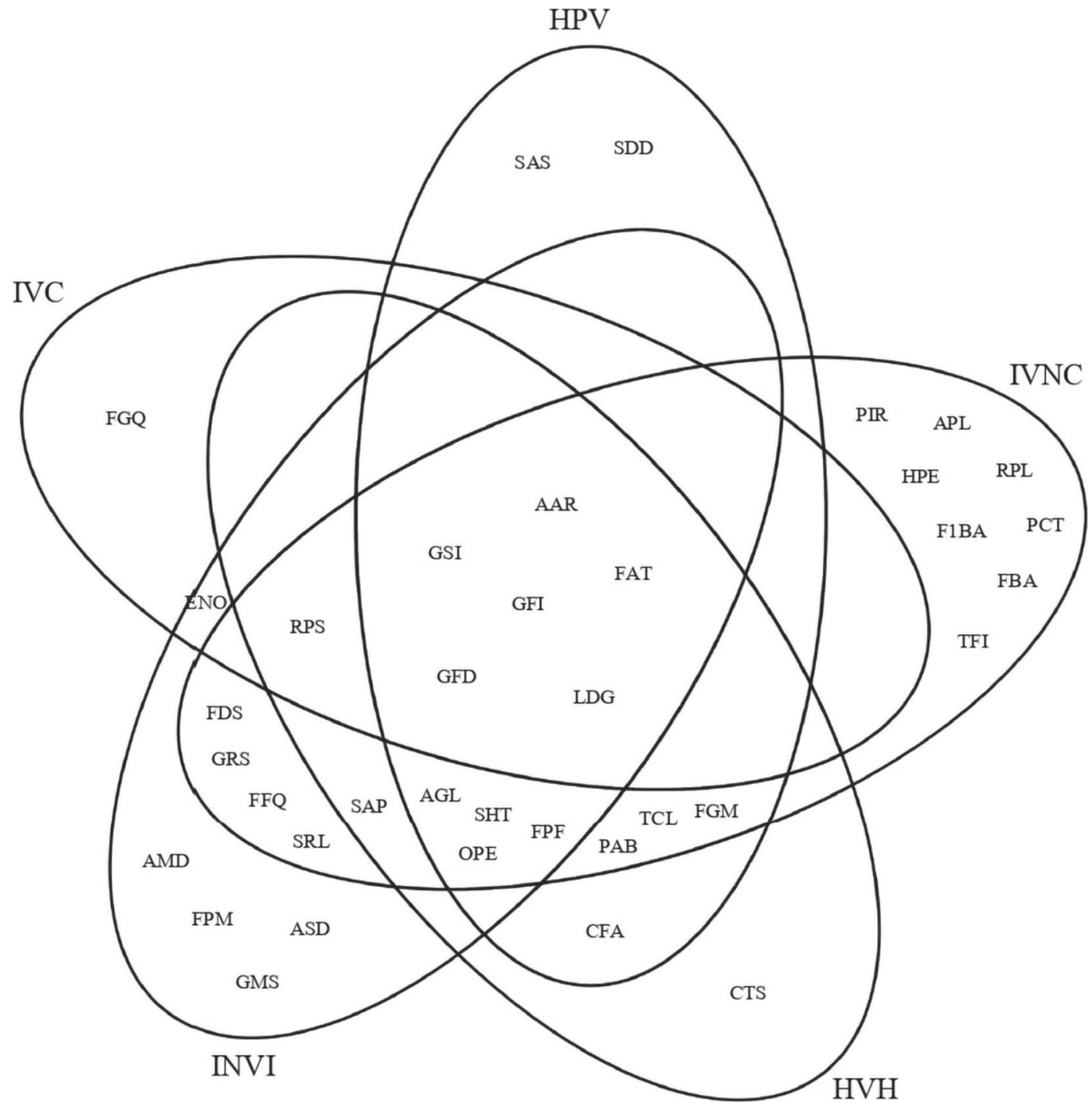

Figure 5. Staphylococcus aureus proteins reactive with sera from animals from the healthy prior to vaccination (HPV); infected, vaccinated, and cured (IVC); infected, vaccinated, not cured (IVNC); infected, not vaccinated, remained infected (INVI); and healthy, vaccinated, and remained healthy $(\mathrm{HVH})$ groups. Venn diagram of $S$. aureus reactive proteins that were selected after 2-dimensional gel electrophoresis and Western blotting using sera from dairy cows from the HPV, IVC, IVNC, INVI, and HVH groups, and identified by MALDI-TOF/TOF. The abbreviations correspond to the identified proteins listed in Table 1. 
energy and intermediary metabolism, protein synthesis and degradation, amino acid synthesis, transcription and replication, and nucleotide metabolism.

Although surface proteins are considered crucial antigens in the prevention of new infections (Anderson et al., 2012; Foster et al., 2014; Misra et al., 2018), cytosolic $S$. aureus proteins are also important antigens that should not be neglected. Some cytoplasmic proteins possess moonlighting functions, displaying distinct functions at different stages; these proteins may also appear extracellularly, and might play an important role in the virulence of the microorganism during infection (Henderson and Martin, 2013).

In an attempt to characterize antigenic $S$. aureus proteins extracted by sonication, Fabres-Klein et al. (2013) found that $52 \%$ of the proteins that reacted with the sera of healthy mice previously challenged with $S$. aureus protein extract were cytosolic. The authors stated that the internalization of these proteins does not preclude their use in serological proteome analyses because the host can build up an immune response and some proteins can be transiently exposed on the cell surface.

In the present study, we used blood serum samples for a serological proteome approach to study a disease of the mammary gland. Misra et al. (2018) used pooled milk samples from acutely clinical mastitic cows and bacteriologically negative healthy cows. However, the antibody titers in milk from healthy mammary glands in dairy cows correlated with blood titers, due to the transudation of plasma antibodies and preferential transport of $\operatorname{IgG}_{1}$ (Fox and Adams, 2000) and $\mathrm{IgG}_{2}$ (Paape et al., 2003). Moreover, the majority of antibody-secreting cells in the blood in a steady state are derived from mucosal immune response, suggesting that compartmentalization between mucosal and systemic plasma cells is less strict than previously thought (Lemke et al., 2016).

We found that SAS and SDD were reactive with the sera of uninfected animals that had no history of $S$. aureus mastitis despite the high prevalence of this pathogen in the studied herds, but they were not reactive with the sera of $S$. aureus-infected animals. Thus, SAS and SDD might stimulate the host immune response in a way that protects animals from natural infections and may be considered predictors of resistance to $S$. aureus mastitis.

We know that SAS is a transmembrane protein that includes $\alpha$ and $\beta$ subunits that are involved in the energy metabolism of the bacterial cell. Studies have demonstrated the antigenic potential of SAS, especially its $\beta$ subunit (Nandakumar et al., 2005; Glowalla et al., 2009; Le Maréchal et al., 2011). Interestingly, although the $\mathrm{F}_{0}$ portion of the protein is membrane-bound, it is the cytosol-facing $\mathrm{F}_{1}$ portion that harbors the $\alpha$ and $\beta$ subunits (Fujisawa et al., 2010).

We found no reports showing that SDD triggers an immune response in the host. This protein catalyzes the hydrolysis of oligopeptides into dipeptides; it is involved in protein synthesis and in the construction of peptidoglycans for the cell wall. The suppression of genes that encode SDD implies that this enzyme is essential for bacterial proliferation and growth (Nocek et al., 2010). Specific antibodies against this protein may inhibit its function, thereby preventing host infection.

The proteins that were reactive with the sera of persistently infected animals (i.e., IPV and INVI groups), but not reactive with the sera of uninfected animals were considered antigenic, given that specific antibodies against these proteins were present in animals that remained chronically infected. Thus, these proteins may not be efficient in the prevention of new infections. Nevertheless, the potential usefulness of these proteins in diagnosis and perhaps even in predicting the prognosis of S. aureus IMI should not be neglected; for example, they might be used to identify dairy cows with lower chances of eliminating $S$. aureus IMI; such cows would be candidates for culling.

Collectively, 13 proteins were reactive with the sera of animals in the IPV and INVI groups (i.e., infected and non-vaccinated animals). The proteins AAC, FGD, FRS, FTT, and GFT stimulated the immune response in IPV animals, whereas ASD, FPM, FFQ, FDS, GRS, GMP and ENO stimulated antibody production in INVI animals. This finding shows variations in the production of specific antibodies against different antistaphylococcal proteins in persistently infected dairy cows.

Based on the results from in the present study, some hypotheses can explain the differences in the production of specific antibodies against $S$. aureus proteins in infected animals. One is that intrinsic differences exist in individual animals' responses to $S$. aureus. The other hypothesis considers that proteins might have differing structures, exposure, and functions at different stages of infection (Cucarella et al., 2004; Tormo et al., 2007; Valle et al., 2007), and that these differences affect the production of antibodies in chronically infected animals.

Generally, only 9 proteins were reactive with the sera of cured animals. Vaccination was exclusively responsible for stimulating the production of specific antibodies against FGQ in cured animals, suggesting that the production of antibodies against this protein is an important feature associated with spontaneous recovery from S. aureus IMI. Hence, FGQ should be incorporated into therapeutic vaccine formulations to increase the likelihood of recovery for chronically infected animals, or 
even into diagnostic kits for predicting the prognosis of animals with $S$. aureus IMI. The importance of this protein is supported by the fact that few other proteins were reactive, suggesting that FGQ is crucial for the spontaneous recovery of infected mammary quarters.

The protein FGQ catalyzes the transfer of a phosphate group from 1,3-bisphosphoglycerate to adenosine diphosphate, and thus plays an important role in $S$. aureus energy metabolism. Given that constant ATP levels are necessary for the cell, this enzyme might be a suitable target for suppression of the glycolytic pathway. It has been suggested that inhibition of FGQ has a negative influence on bacterial populations during biofilm formation and may be involved in resistance to antimicrobials (Becker et al., 2001). As well, FGQ might have different domains and display different interactions (Roychowdhury et al., 2011).

Although they were antigenic, the remaining proteins (except for ENO) that were reactive with the sera of IVC animals were not considered predictors of cure, because they were also reactive with the sera of infected animals that were not cured after vaccination (IVNC). Even though the ENO protein was reactive with the sera of INVI animals, vaccination was responsible for the stimulation of the immune response against ENO, followed by animals' recovery. Thus, we also considered ENO to be a promising predictor of recovery.

We know that ENO is a moonlighting protein that contains a structural region anchored to the bacterial cell membrane; this region of the protein binds directly to the laminin of the host's basement membrane. In the cytoplasm, ENO participates in the glycolytic pathway by converting 2-phospho-D-glycerate into phosphoenolpyruvate, which in turn produces pyruvate and acetylcoA. Acetate metabolism can affect bacterial autolysis during cell division and cell wall peptidoglycan repair. Thus, ENO might be involved in bacterial autolysis (Patton et al., 2005; Yu et al., 2011). Several studies have found that ENO reacts with the sera of infected hosts (Dryla et al., 2005; Burlak et al., 2007; Le Maréchal et al., 2011; Le Maréchal et al., 2013). Glowalla et al. (2009) showed that ENO could prevent new infections after vaccination and microbiological challenge with $S$. aureus in mice. Under these conditions, $\operatorname{IgG}_{1}, \operatorname{IgG}_{2}$, and $\mathrm{IgG}_{3}$ levels were increased, as were opsonization and phagocytosis by polymorphonuclear leukocytes.

In the present study, vaccination also stimulated the production of specific antibodies against F1BA, FBA, RPL, HPE, PCT, and PIR in animals that had not been cured of $S$. aureus IMI (IVNC), but these proteins were not reactive with the sera from IPV animals. The observed infection-vaccine synergy indicates that these proteins are important antigens. However, the production of specific antibodies against these proteins was not associated with animals' spontaneous recovery and may be associated with a poor prognosis for bacteriological cure after vaccination.

In the present study, CTS was reactive only to the sera of healthy animals after vaccination; vaccination of infected animals did not stimulate the production of this protein. These findings do not exclude CTS as a predictor of prevention, but the protein must be better understood with respect to the host response. Its potential use as a predictor of the prevention of new IMI cannot be neglected, because we hypothesize that variations in the recognition and production of antibodies against distinct $S$. aureus proteins probably result from the inherent variability of the host to infections (Souza et al., 2019).

During protein synthesis, transfer RNA (tRNA) carries and transfers amino acids to the ribosome during messenger RNA codon translation; CTS is an aminoacyl-tRNA enzyme that catalyzes the binding of a specific amino acid to tRNA, but it can also attach the amino acid to other molecules (Nagaev et al., 2001). Because the serum of HVH animals was reactive with CTS, this protein might possess an extracellular domain. Islam et al. (2014) considered other aminoacyltRNA synthetases extracted from $S$. aureus (such as prolyl- and glutamyl-tRNA synthetases) to be transmembrane proteins. Conversely, glycyl-tRNA synthetase was not considered to be a transmembrane protein. Other studies have demonstrated the antigenic potential of aspartyl- and alanyl-tRNA synthetases extracted from S. aureus (Le Maréchal et al., 2011; Seyffert et al., 2012). However, the authors of that study reported that these proteins were cytoplasmic. To date, we have found no reports that CTS extracted from $S$. aureus is antigenic in cattle.

Most studies report that proteins that trigger immune responses in only infected hosts are potential candidates for the production of vaccines against $S$. aureus. The findings of the present study suggest that proteins that were reactive with the sera of healthy animals that had no history of $S$. aureus mastitis, as well as with the sera of infected animals that had been cured of $S$. aureus IMI after vaccination, were of interest as potential candidates for preventing new IMI and for spontaneous recovery from IMI caused by $S$. aureus.

Although the sample size in this study was limited, the information gathered could be generated only by using serum obtained from healthy animals and from those naturally infected with $S$. aureus. Dryla et al. (2005) warn that efficient strategies for the selection of antigenic proteins should be based on the immune responses of the animals. The suggestions proposed in this report can be confirmed by conducting new experiments to determine whether vaccines that include 
the suggested antigens confer prevention and cure of mastitis caused by a wide array of $S$. aureus samples isolated from different herds. Further studies should also explore secreted virulence factors to achieve an effective staphylococcal vaccine (Giersing et al., 2016).

\section{CONCLUSIONS}

The present study identified cytoplasmic and membrane-bound $S$. aureus proteins related to specific antibodies found in the sera of infected and uninfected cattle at different times after infection. Vaccination of the animals stimulated the production of anti-staphylococcal antibodies against proteins that were previously nonreactive with the sera of infected and healthy animals. The most important finding of our study was that SAS, SDD, and CTS are novel candidate proteins for the prevention of bovine $S$. aureus mastitis, and that FGQ and ENO are potential candidates for predicting recovery. The results of the present study strengthen the idea that variations in animals' immune responses should not be ignored, and show that the heterogeneity of antibody production against anti-staphylococcal antigens in animals may enable the identification of new targets for immunotherapy.

\section{ACKNOWLEDGMENTS}

The authors are grateful to Fundação de Amparo à Pesquisa do Estado de Minas Gerais (Process number APQ-02210-13), Conselho Nacional de Desenvolvimento Científico e Tecnológico (CNPq; Process number 481950/2013-3), and Coordinator for the Improvement of Higher Education Personnel (CAPES) for financial support. HAM, MG, HG, MAVPB, AMMPDL, APL, and $\mathrm{MBH}$ thank the $\mathrm{CNPq}$ for their fellowships. FNS thanks the São Paulo State Research Foundation for his fellowship (Process number 2014/23189-4). The funders had no role in the study design, data collection and analysis, decision to publish, or preparation of the manuscript.The authors have not stated any conflicts of interest.

\section{REFERENCES}

Anderson, A. S., A. A. Miller, R. G. K. Donald, I. L. Scully, J. S. Nanra, D. Cooper, and K. U. Jansen. 2012. Development of a multicomponent Staphylococcus aureus vaccine designed to counter multiple bacterial virulence factors. Hum. Vaccin. Immunother. 8:1585-1594. https://doi.org/10.4161/hv.21872.

Becker, P., W. Hufnagle, G. Peters, and M. Herrmann. 2001. Detection of differential gene expression in biofilm-forming versus planktonic populations of Staphylococcus aureus using Micro-Representational-Difference analysis. Appl. Environ. Microbiol. 67:2958-2965. https://doi.org/10.1128/AEM.67.7.2958-2965.2001.
Bradford, M. M. 1976. A rapid and sensitive method for the quantification of microgram quantities of protein utilizing the principle of protein-dye binding. Anal. Biochem. 72:248-254. https://doi.org/ 10.1016/0003-2697(76)90527-3.

Burlak, C., C. H. Hammer, M. A. Robinson, A. R. Whitney, M. J. Mcgavin, B. N. Kreiswirth, and F. R. Deleo. 2007. Global analysis of community-associated methicillin-resistant Staphylococcus aureus exoproteins reveals molecules produced in vitro and during infection. Cell. Microbiol. 9:1172-1190. https://doi.org/10.1111/j.1462 $-5822.2006 .00858 . x$.

Cucarella, C., M. A. Tormo, C. Úbeda, M. P. Trotonda, M. Monzón, C. Peris, B. Amorena, I. Lasa, and J. R. Penadés. 2004. Role of Biofilm-Associated Protein Bap in the pathogenesis of bovine Staphylococcus aureus. Infect. Immun. 72:2177-2185. https://doi .org/10.1128/IAI.72.4.2177-2185.2004.

da Fonseca Pires, S., L. C. Fialho Jr, S. O. Silva, M. N. Melo, C. C. de Souza, W. L. Tafuri, O. Bruna Romero, and H. M. de Andrade. 2014. Identification of virulence factors in Leishmania infantum strains by a proteomic approach. J. Proteome Res. 13:1860-1872. https://doi.org/10.1021/pr400923g.

De Vliegher, S., L. K. Fox, S. Piepers, S. McDougall, and H. W. Barkema. 2012. Invited review: Mastitis in dairy heifers: Nature of disease, potential impact, prevention, and control. J. Dairy Sci. 95:1025-1040. https://doi.org/10.3168/jds.2010-4074.

Dryla, A., S. Prustomersky, D. Gelbmann, M. Hanner, E. Bettinger, B. Kocsis, T. Kustos, T. Henics, A. Meinke, and E. Nagy. 2005. Comparison of antibody repertoires against Staphylococcus aureus in healthy individuals and in acutely infected patients. Clin. Diagn. Lab. Immunol. 12:387-398. https://doi.org/10.1128/CDLI.12 $.3 .387-398.2005$.

Fabres-Klein, M. H., R. C. Klein, S. O. De Paula, and A. O. B. Ribon. 2013. Immunorelevant proteins for the diagnosis of bovine staphylococcal mastitis. World J. Microbiol. Biotechnol. 29:1155-1160. https://doi.org/10.1007/s11274-013-1274-8.

Foster, T. J., J. A. Geoghegan, V. K. Ganesh, and M. Höök. 2014. Adhesion, invasion and evasion: The many functions of the surface proteins of Staphylococcus aureus. Nat. Rev. Microbiol. 12:49-62. https://doi.org/10.1038/nrmicro3161.

Fox, L. K., and D. S. Adams. 2000. The ability of the enzyme-linked immunosorbent assay to detect antibody against Staphylococcus aureus in milk following experimental intramammary infection. J. Vet. Med. B Infect. Dis. Vet. Public Health 47:517-526. https:// doi.org/10.1046/j.1439-0450.2000.00379.x.

Francius, G., O. Domenech, M. Mingeot-Leclercq, and Y. Dufrêne. 2008. Direct observation of Staphylococcus aureus cell wall digestion by lysostaphin. J. Bacteriol. 190:7904-7909. https://doi.org/ 10.1128/JB.01116-08.

Fujisawa, M., O. J. Fackelmayer, J. Liu, T. A. Krulwich, and D. B. Hicks. 2010. The ATP synthase a-subunit of extreme alkaliphiles is a distinct variant. J. Biol. Chem. 285:32105-32115. https://doi .org/10.1074/jbc.M110.165084.

Giersing, B. K., S. S. Dastgheyhb, K. Modjarrad, and V. Moorthy. 2016. Status of vaccine research and development of vaccines for Staphylococcus aureus. Vaccine 34:2962-2966. https://doi.org/10 $.1016 /$ j.vaccine.2016.03.110.

Glowalla, E., B. Tosetti, M. Krõnke, and O. Krut. 2009. Proteomicsbased identification of anchorless cell wall proteins as vaccine candidates against Staphylococcus aureus. Infect. Immun. 77:27192729. https://doi.org/10.1128/IAI.00617-08.

Halasa, T., M. Nielen, R. B. M. Huirne, and H. Hogeveen. 2009. Stochastic bio-economic model of bovine intramammary infection. Livest. Sci. 124:295-305. https://doi.org/10.1016/j.livsci.2009.02 019 .

Henderson, B., and A. Martin. 2013. Bacterial moonlighting proteins and bacterial virulence. Curr. Top. Microbiol. Immunol. 358:155213.

Holtfreter, S., J. Kolata, and B. M. Bröker. 2010. Towards the immune proteome of Staphylococcus aureus - the anti-S. aureus antibody response. Int. J. Med. Microbiol. 300:176-192. https://doi.org/10 $.1016 /$ j.ijmm.2009.10.002. 
Hospido, A., and U. Sonesson. 2005. The environmental impact of mastitis: A case study of dairy herds. Sci. Total Environ. 343:7182. https://doi.org/10.1016/j.scitotenv.2004.10.006.

Islam, N., Y. Kim, J. M. Ross, and M. R. Marten. 2014. Proteomic analysis of Staphylococcus aureus biofilm cells grown under physiologically relevant fluid shear stress conditions. Proteome Sci. 12:21. https://doi.org/10.1186/1477-5956-12-21.

Le Maréchal, C., G. Jan, S. Even, J. A. Mcculloch, V. Azevedo, R. Thiéry, E. Vautor, and Y. Le Loir. 2009. Development of serological proteome analysis of mastitis by Staphylococcus aureus in ewes. J. Microbiol. Methods 79:131-136. https://doi.org/10.1016/ j.mimet.2009.08.017.

Le Maréchal, C., J. Jardin, V. Briard-Bion, L. Rault, N. Berkova, E. Vautor, R. Thiéry, S. Even, and Y. Le Loir. 2013. Staphylococcus aureus proteins differentially produced in ewe gangrenous mastitis or ewe milk. Vet. Microbiol. 164:150-157. https://doi.org/10.1016/ j.vetmic.2013.01.013.

Le Maréchal, C., N. Seyffert, J. Jardin, D. Hernandez, G. Jan, L. Rault, V. Azevedo, P. François, J. Schrenzel, M. van de Guchte, S. Even, N. Berkova, R. Thiéry, J. R. Fitzgerald, E. Vautor, and Y. Le Loir. 2011. Molecular basis of virulence in Staphylococcus aureus mastitis. PLoS One 6:e27354. https://doi.org/10.1371/ journal.pone.0027354.

Lemke, A., M. Kraft, K. Roth, R. Riedel, D. Lammerding, and A. E. Hauser. 2016. Long-lived plasma cells are generated in mucosal immune responses and contribute to bone narrow plasma cell pool in mice. Mucosal Immunol. 9:83-97. https://doi.org/10.1038/mi .2015.38.

McDougal, L. K., C. D. Steward, G. E. Killgore, J. M. Chaitram, S. K. McAllister, and F. C. Tenover. 2003. Pulsed-field gel electrophoresis typing of oxacillin-resistant Staphylococcus aureus isolates from the United States: Establishing a national database. J. Clin. Microbiol. 41:5113-5120. https://doi.org/10.1128/JCM.41.11.5113 $-5120.2003$

Mehrotra, M., G. Wang, and W. M. Johnson. 2000. Multiplex PCR for detection of genes for Staphylococcus aureus enterotoxins, exfoliative toxins, toxic shock syndrome toxin 1 , and methicillin resistance. J. Clin. Microbiol. 38:1032-1035.

Misra, N., X. Pu, D. N. Holt, M. A. McGuire, and J. K. Tinker. 2018. Immunoproteomics to identify Staphylococcus aureus antigens expressed in bovine milk during mastitis. J. Dairy Sci. 101:62966309. https://doi.org/10.3168/jds.2017-14040.

Moura, G. S., W. A. Gebreyes, M. F. S. Marques, D. T. Stipp, F. N. Souza, L. B. Da Costa, and C. J. B. Oliveira. 2018. Short communication: Occurrence of methicillin-resistant Staphylococcus aureus and coagulase-negative staphylococci in dairy goats herds in Ohio, United States. J. Dairy Sci. 101:7804-7807. https://doi.org/ $10.3168 /$ jds. $2017-13361$.

Nagaev, I., J. Bjõrkman, A. I. Andersson, and D. Hughes. 2001. Biological cost and compensatory evolution in fusidic acid-resistant Staphylococcus aureus. Mol. Microbiol. 40:433-439. https://doi .org/10.1046/j.1365-2958.2001.02389.x.

Nandakumar, R., M. P. Nandakumar, M. R. Marten, and J. M. Ross. 2005. Proteome analysis of membrane and cell wall associated proteins from Staphylococcus aureus. J. Proteome Res. 4:250-257. https://doi.org/10.1021/pr049866k.

Neuhoff, V., N. Arold, D. Taube, and W. Ehrhardt. 1988. Improved staining of proteins in polyacrylamide gels including isoelectric focusing gels with clear background at nanogram sensitivity using Coomassie Brilliant Blue G-250 and R-250. Electrophoresis 9:255-262. https://doi.org/10.1002/elps.1150090603.

Nocek, B. P., D. M. Gillner, Y. Fan, R. C. Holz, and A. Joachimiak. 2010. Structural basis for catalysis by the mono- and dimetalated forms of the dapE-encoded N-succinyl-L,L-diaminopimelic acid desuccinylase. J. Mol. Biol. 397:617-626. https://doi.org/10.1016/j .jmb.2010.01.062.

Oliver, S. P., R. N. González, J. S. Hogan, B. M. Jayarao, and W. E. Owens. 2004. Microbiological procedures for the diagnosis of bovine udder infection and determination of milk quality. National Mastitis Council, Verona, WI.
Paape, M. J., D. D. Bannerman, X. Zhao, and J. W. Lee. 2003. The bovine neutrophil: Structure and function. Vet. Res. 34:597-627. https://doi.org/10.1051/vetres:2003024.

Patton, T. G., K. C. Rice, M. K. Foster, and K. W. Bayles. 2005 The Staphylococcus aureus cidC gene encodes a pyruvate oxidase that affects acetate metabolism and cell death in stationary phase. Mol. Microbiol. 56:1664-1674. https://doi.org/10.1111/j.1365 $-2958.2005 .04653 . x$.

Pereira, U. P., D. G. S. Oliveira, L. R. Mesquita, G. M. Costa, and L. J. Pereira. 2011. Efficacy of Staphylococcus aureus vaccines for bovine mastitis: A systematic review. Vet. Microbiol. 148:117-124. https://doi.org/10.1016/j.vetmic.2010.10.003.

Rainard, P., G. Foucras, J. R. Fitzgerald, J. L. Watts, G. Koop, and J. R. Middleton. 2018. Knowledge gaps and research priorities in Staphylococcus aureus mastitis control. Transbound. Emerg. Dis. 65(Suppl. 1):149-165. https://doi.org/10.1111/tbed.12698.

Richardson, E. J., R. Bacigalupe, E. M. Harrison, L. A. Weinert, S. Lycett, M. Vrieling, K. Robb, P. A. Hoskisson, M. T. G. Holden, E. J. Feil, G. K. Paterson, S. T. C. Tong, A. Shittu, W. van Wamel, D. M. Aanensen, J. Parkhill, S. J. Peacock, J. Corander, M. Holmes, and J. R. Fitzgerald. 2018. Gene exchange drives the ecological success of a multi-host bacterial pathogen. Nat. Ecol. Evol. 2:1468-1478. https://doi.org/10.1038/s41559-018-0617-0.

Roychowdhury, A., S. Mukherjee, and A. K. Das. 2011. Expression, purification, crystallization and preliminary X-ray diffraction studies of phosphoglycerate kinase from methicillin-resistant Staphylococcus aureus MRSA252. Acta Crystallogr. Sect. F Struct. Biol. Cryst. Commun. 67:668-671. https://doi.org/10.1107/ S1744309111007391.

Rueckert, C., and C. A. Guzmán. 2012. Vaccines: From empirical development to rational design. PLoS Pathog. 8:e1003001. https:// doi.org/10.1371/journal.ppat.1003001.

Ruegg, P. L. 2017. A 100-year review: Mastitis detection, management, and prevention. J. Dairy Sci. 100:10381-10397. https://doi .org/10.3168/jds.2017-13023.

Salgado-Pabón, W., and P. M. Schlievert. 2014. Models matter: The search for an effective Staphylococcus aureus vaccine. Nat. Rev. Microbiol. 12:585-591. https://doi.org/10.1038/nrmicro3308.

Sasaki, T., S. Tsubakishita, Y. Tanaka, A. Sakusabe, M. Ohtsuka, S. Hirotaki, T. Kawakami, T. Fukata, and K. Hiramatsu. 2010. Multiplex-PCR method for species identification of coagulase-positive staphylococci. J. Clin. Microbiol. 48:765-769. https://doi.org/10 .1128/JCM.01232-09.

Schepers, A. J., T. J. G. M. Lam, Y. H. Schukken, J. B. M. Wilmink, and W. J. A. Hanekamp. 1997. Estimation of variance components for somatic cell counts to determine threshold for uninfected quarters. J. Dairy Sci. 80:1833-1840. https://doi.org/10.3168/jds .S0022-0302(97)76118-6.

Schukken, Y. H., V. Bronzo, C. Locatelli, C. Pollera, N. Rota, A. Casula, F. Testa, L. Scaccabarozzi, R. March, D. Zalduendo, R. Guix, and P. Moroni. 2014. Efficacy of vaccination on Staphylococcus aureus and coagulase-negative staphylococci intramammary infection dynamic in 2 dairy herds. J. Dairy Sci. 97:5250-5264. https:/ /doi.org/10.3168/jds.2014-8008.

Schukken, Y. H., D. J. Wilson, F. Welcome, L. Garrison-Tikofsky, and R. N. Gonzalez. 2003. Monitoring udder health and milk quality using somatic cell counts. Vet. Res. 34:579-596. https://doi.org/10 .1051/vetres:2003028.

Seyffert, N., C. Le Maréchal, J. Jardin, J. A. McCulloch, F. R. Rosado, A. Miyoshi, S. Even, G. Jan, N. Berkova, E. Vautor, R. Thiéry, V. Azevedo, and Y. Le Loir. 2012. Staphylococcus aureus proteins differentially recognized by the ovine immune response in mastitis or nasal carriage. Vet. Microbiol. 157:439-447. https://doi.org/10 .1016/j.vetmic.2012.01.016.

Souza, F. N., A. F. Cunha, D. L. S. O. Rosa, M. A. V. Brito, A. S. Guimarães, L. C. Mendonça, G. N. Souza, A. P. Lage, M. G. Blagitz, A. M. M. P. Della Libera, M. B. Heinemann, and M. M. O. P. Cerqueira. 2016. Somatic cell count and mastitis pathogen detection in composite and single or duplicate quarter milk sam- 
ples. Pesqui. Vet. Bras. 36:811-818. https://doi.org/10.1590/s0100 $-736 \times 2016000900004$.

Souza, F. N., E. M. R. Sanchez, A. M. M. P. Della Libera, and M. B. Heinemann. 2019. Letters to the editor: A comment on "Control of bovine mastitis in the 21st century: Immunize or tolerate? Res. Vet. Sci. 126:20-21.

Tedeschi, G., F. Taverna, A. Negri, R. Piccinini, S. Nonnis, S. Ronchi, and A. Zecconi. 2009. Serological proteome analysis of Staphylococcus aureus isolated from sub-clinical mastitis. Vet. Microbiol. 134:388-391. https://doi.org/10.1016/j.vetmic.2008.08.019.

Tormo, M. A., C. Úbeda, M. Martí, E. Maiques, C. Cucarella, J. Valle, T. J. Foster, I. Lasa, and J. R. Penadés. 2007. Phase-variable expression of the biofilm-associated protein (Bap) in Staphylococcus aureus. Microbiology 153:1702-1710. https://doi.org/10.1099/mic $.0 .2006 / 005744-0$.

Valle, J., M. Vergara-Irigaray, N. Merino, J. R. Penadés, and I. Lasa. 2007. $\sigma^{\mathrm{B}}$ regulates IS256-mediated Staphylococcus aureus biofilm phenotypic variation. J. Bacteriol. 189:2886-2896. https://doi .org/10.1128/JB.01767-06. van Belkum, A., P. T. Tassios, L. Dijkshoorn, S. Haeggman, B. Cookson, N. K. Fry, V. Fussing, J. Green, E. Feil, P. Gerner-Smidt, S. Brisse, and M. Struelens. 2007. Guidelines for the validation and application of typing methods for use in bacterial epidemiology. Clin. Microbiol. Infect. 13(Suppl. 3):1-46. https://doi.org/10 $.1111 / j .1469-0691.2007 .01786 . x$

Vieira, H. G. S., P. Grynberg, M. Bitar, S. F. Pires, H. O. Hilário, A. M. Macedo, C. R. Machado, H. M. de Andrade, and R. G. Franco. 2014. Proteomic analysis of Trypanosoma cruzi response to ioning radiation. PLoS One 9:e97526. https://doi.org/10.1371/ journal.pone.0097526.

Vytvytska, O., E. Nagy, M. Blüggel, H. E. Meyer, R. Kurzbauer, L. A. Huber, and C. S. Klade. 2002. Identification of vaccine candidate antigens of Staphylococcus aureus by serological proteome analysis. Proteomics 2:580-590. https://doi.org/10.1002/1615 $-9861(200205) 2: 5<580:$ AID-PROT580>3.0.CO:2-G.

Yu, X., L. Zheng, J. Yang, T. Lei, and Y. Ji. 2011. Characterization of essential enolase in Staphylococcus aureus. World J. Microbiol. Biotechnol. 27:897-905. https://doi.org/10.1007/s11274-010-0532-2. 